\title{
МGenome Biology
}

\section{Comment \\ Nation of twits}

Gregory A Petsko

Address: Rosenstiel Basic Medical Sciences Research Center, Brandeis University, Waltham, MA 02454-9110, USA. Email: petsko@brandeis.edu

I think what finally did it for me was when the Pope got a Facebook page. True, there were warning signs: on 22 July 2009, the crew of the space shuttle Endeavor, orbiting high above the planet, communicated with the earth using Twitter and YouTube. But such minor pandering to youth culture pales into insignificance beside the sight of the smiling face of Pope Benedict XVI, greeting visitors to his unfortunately named website Pope2You.net (I am not making this up), where you can download the application 'Pope2You for Facebook' which, to quote the site, "lets you receive the messages of Pope Benedict XVI through the most important social network of the world. So you can meet the Pope on Facebook, listen to his words, see his pictures, and receive his messages of congratulations through 'virtual postcards'. The postcards can be sent to your 'friends' on Facebook and the application can be shared with anyone. So we can create a close sharing network around our Pope." This, you will recall, is the same Pope who last year issued a well-publicized warning about the dangers of technology.

Social networking is to the latter part of this decade what the Internet was to the 1990s: a technology that both typifies the era and shapes it. In 2000, Harvard University political science professor Robert D Putnam wrote a wellreceived book, Bowling Alone (an expanded version of an article he had published five years earlier in the Journal of Democracy), in which he sounded the warning that all forms of in-person social intercourse were declining, owing to the technological 'individualizing' of our leisure time via television, the Internet and eventually 'virtual reality helmets'. It's hard to imagine he could have been more wrong. True, the older generation might have viewed technology such as the Internet as leading to increased isolation, but the younger generation has exploited it for exactly the opposite purpose: as a way of building interpersonal ties. The hottest technology companies in the world right now are the ones that create and maintain socialnetworking sites: namely Facebook, which allows people to advertise themselves on the World Wide Web; LinkedIn, a kind of Facebook for professionals looking to advance their careers; YouTube, a site for sharing videos; and Twitter, a site that basically takes the concept of the text messages so beloved of cell-phone-toting teenagers and allows users to post them as 140-character limit 'tweets', where they can be seen by enormous number of people.

It's easy to see why Twitter has become the social network $d u$ jour, at least in the United States. It provides the illusion of human contact without the messy reality. The 140-character tweets are perfect for an age of short attention spans and minimal literacy. And it gives people a glimpse into the daily lives of celebrities and other glamorous folk.

The problem is that, once you actually take such a glimpse, you quickly discover that the daily lives of most glamorous folk are pretty much just like our own: not merely unglamorous but often downright dull. Here, for example, is a tweet from one Chris Cooley, a professional US football player for the Washington Redskins team, sent on the opening day of training camp this year: "Had a six inch Sub for lunch and now I'm headed back to practice number 2. Ugh." Wow. Talk about inside information. Makes you wonder who would waste their time reading this, doesn't it?

Well, the answer, in Chris Cooley's case, is about 12,00o people, who apparently find such 'insights' riveting. That's how many Twitter 'followers' he has, that is, people who have signed up to receive his every tweet as soon as they are posted.

The wrong tweet can get you into all sorts of trouble. Just ask Antonio Cromartie, another US football player (what is it with these guys?) who was recently pulled out of a team meeting and fined $\$ 2,500$ for the following tweet: "Man we have 2 have the most nasty food of any team. Damn can we upgrade 4 str 8 years the same ish maybe that's $y$ we can't win the $S B$ we need." That's right, Cromartie was fined $\$ 17.86$ for each of the 140 characters of his complaint about training-camp food. At those prices he could have taken out a full-page ad in the local newspaper.

Except, of course, that young people aren't reading newspapers. Instead, they're getting their information from Twitter. And sometimes that's not a bad thing. During the recent political unrest in Iran, most of the authentic news 
leaking out of that country came in the form of tweets from Iranians and foreigners who happened to be there. (Of course, anything important will quickly be exploited by capitalists, and businesses have already been caught using Twitter and other social-networking sites as a way of spreading sales pitches about their products and misinformation about their competitors, all disguised as 'objective' tweets from disinterested parties.) That's how useful Twitter can be, and it's likely to become more important in the future, as a means of overcoming censorship, for example.

Even US President Barack Obama is getting into the act. His Twitter page, which has 2,045,875 followers, contains observations such as this: History was made today when Sonia Sotomayor took the judicial oath and joined the Supreme Court. Congratulations, Justice.1:31 PM Aug $8^{\text {th }}$

Still, it is the mind-numbing banality of the activities of virtually every person who tweets regularly that truly impresses. Here, for example, is a tweet from former VicePresidential candidate Sarah Palin, posted the day before she resigned as Governor of Alaska: "Wrapped up Anch Gov's Picnic, awesome. Now road trip to Fairbanks for farewell speech/changing of the guard. Camper full of kids \& coffee." Where else can her 139,667 Twitter followers get that kind of political scoop?

Do a search for 'genomics' on Twitter and you get a number of genome biologists who tweet regularly. Here are some completely representative tweets from several of them, in no particular order:

The mutt is panting \& hiding behind the couch thunderstorms must be close now....5:46 AM May $16^{\text {th }}$

milk was a bad choice 12:22 PM Aug 21 ${ }^{\text {st }}$

(I checked to see if there was any follow-up to this one, but there wasn't, so we don't know if the choice was bad because of spoiled milk, some religious prohibition against dairy products, or whatever)

ooooo savin up my moneyyyy to buy a new dishwashaaaa 4:31 PM Aug 19 ${ }^{\text {th }}$

ACLU sues over patents on breast cancer genes http://bit.ly/KuRBE \#cnn4:32 AM May 13 $3^{\text {th }}$

(Now this is actually informative, and an example of something that does happen frequently on Twitter: the tweet contains a link to a web page with some information typically a news story. One function of this social network is for members to alert each other to things of mutual interest.)

Sneezing up a storm, I must have fried a trillion brain cells so far - hope this cold is over soon, I don't have that many to spare! 5:18 AM Apr 29 ${ }^{\text {th }}$
Ontario Institute for Cancer Research (OICR) to Use Helicos'Single Molecule Sequencing Technology http:// bit.ly/9n9Mq \#genomics \#ngs11:oo PM Aug 20 ${ }^{\text {th }}$

$R T @$ RibogeniX: Yes.. there is an app for that!! calculates Tm, protein, DNA concentrations etc, etc on iphone http://ow.ly/kUWR6:48 PM Aug 21 ${ }^{\text {st }}$

(This is another example of the usefulness of tweeting. RT means 'reply to' and @RibogeniX is the Tweeter ID of someone who apparently asked a question about whether there was an application for the iPhone that performed some calculations they needed. This sort of sharing of advice happens frequently on Twitter.)

Watching election update 9:24 PM Nov $4^{\text {th }}, 2008$

new word of the day: Infovore, one that is a voracious consumer of information 8:34 AM Aug $12^{\text {th }}$

practicing procrastination. I just don't feel like doing laundry tonight 5:35 PM Apr 10 th

That pretty much sums up Twitter, at least in my experience: occasional flashes of insight or information mixed in with an amazing amount of trivialities. The motto of Twitter is "What are you doing?" and you can see that, even in the case of genome biologists, the answer would often appear to be, "Not much that should interest anybody." Except that, for whatever reason, it does: the average genome biologist has between 50 and 200 followers on Twitter.

Twitter is probably the ultimate example of the triumph of the 'Me' generation. Its very premise, that everybody's most insignificant thoughts or experiences are de facto interesting to someone, and maybe a lot of someones, and therefore are of great intrinsic importance, carries the solipsistic notion that "I am the cosmos" about as far as it can be carried. Twitter also is reducing the English language to misspelled shorthand and is training a generation to substitute emoticons (e.g. : ( for sadness) for genuine descriptions of real human emotions. Imagine William Faulkner's great novel The Sound and the Fury written by one who was raised on Twitter. We'd get The Snd \& the : \{

That said, Twitter, and other social-networking sites, do provide a way for certain communities to make contact and remain connected. Social networking online also encourages brevity, although from my experience, that has yet, on Twitter at least, to become the soul of wit.

But Im L8 4 walkng dogs so no more column 4 now. $U$ can xpect nxt column 2 b about sumthng more important.

Published: 28 August 2009

doi:10.1186/gb-2009-10-8-110

(C) 2009 BioMed Central Ltd 